\title{
School Climate and its Influence on Organizational Citizenship Behavior: A Theoretical Framework
}

Suriani Ismail, Ismi Arif Ismail, Zoharah Omar, Siti Noormi Alias, Ahmad Aizuddin Md Rami

To Link this Article: http://dx.doi.org/10.6007/IJARBSS/v11-i6/9926

DOI:10.6007/IJARBSS/v11-i6/9926

Received: 10 April 2021, Revised: 30 April 2021, Accepted: 19 May 2021

Published Online: 14 June 2021

In-Text Citation: (Ismail et al., 2021)

To Cite this Article: Ismail, S., Ismail, I. A., Omar, Z., Alias, S. N., \& Rami, A. A. M. (2021). School Climate and its Influence on Organizational Citizenship Behavior: A Theoretical Framework. International Journal of Academic Research in Business and Social Sciences, 11(6), 410-424.

Copyright: (C) 2021 The Author(s)

Published by Human Resource Management Academic Research Society (www.hrmars.com)

This article is published under the Creative Commons Attribution (CC BY 4.0) license. Anyone may reproduce, distribute, translate and create derivative works of this article (for both commercial and non-commercial purposes), subject to full attribution to the original publication and authors. The full terms of this license may be seen

at: http://creativecommons.org/licences/by/4.0/legalcode

Vol. 11, No. 6, 2021, Pg. 410 - 424

Full Terms \& Conditions of access and use can be found at http://hrmars.com/index.php/pages/detail/publication-ethics 


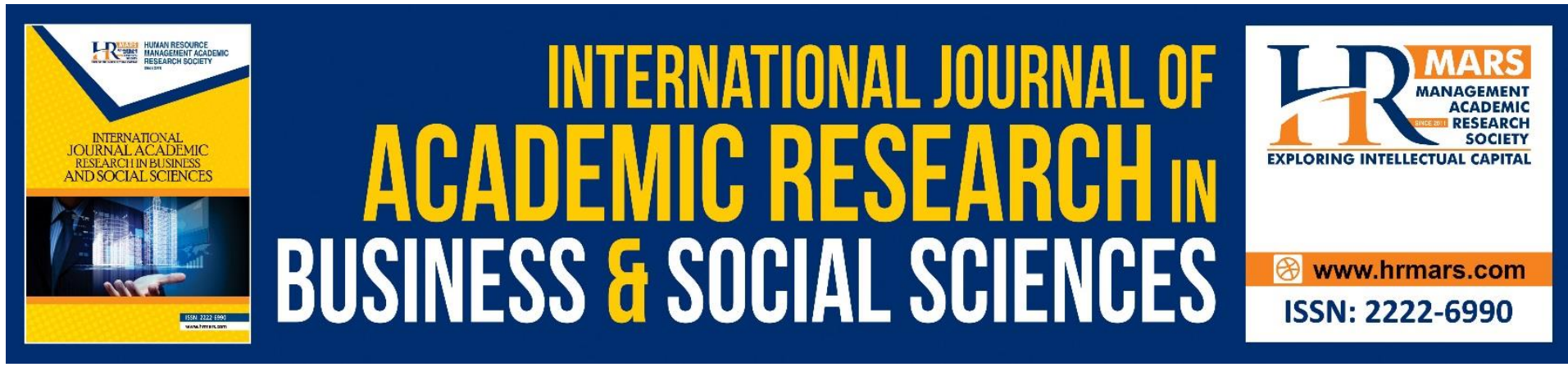

\title{
School Climate and its Influence on Organizational Citizenship Behavior: A Theoretical Framework
}

\author{
Suriani Ismail ${ }^{1}$, Ismi Arif Ismail ${ }^{2}$, Zoharah Omar ${ }^{3}$, Siti Noormi \\ Alias ${ }^{4}$, Ahmad Aizuddin Md Rami ${ }^{5}$ \\ ${ }^{1}$ Faculty of Educational Studies, Universiti Putra Malaysia, 43400 UPM, Serdang Selangor, \\ Malaysia, ${ }^{2}$ Elektrisola (Malaysia) Sdn. Bhd, Jalan Damai 1, Janda Baik, 28750 Bentong, \\ Pahang, Malaysia, ${ }^{3}$ Faculty of Educational Studies, Universiti Putra Malaysia, 43400 UPM, \\ Serdang Selangor, Malaysia, ${ }^{4}$ Faculty of Educational Studies, Universiti Putra Malaysia, \\ 43400 UPM, Serdang, Selangor, Malaysia, ${ }^{5}$ Faculty of Educational Studies, Universiti Putra \\ Malaysia, 43400 UPM, Serdang Selangor, Malaysia.
}

Email: suesyaurahism@gmail.com,zoharah@elektrisola.my, ismi@upm.edu.my, sitinoormi@upm.edu.my, ahmadaizuddin@upm.edu.my

\begin{abstract}
Organizational citizenship behavior (OCB) refers to the behavior of employees, which typically exceeds their official duties. This behavior is important because it helps to enhance employees' performance and lead organizations to become more innovative and productive. Many studies on OCB have been conducted in organizations. However, limited literature can be found in the context of educational practices. Hence, the purpose of this conceptual paper is to explore deeper into OCB within an educational context. A comprehensive review of the literature has identified a factor that can potentially influence $O C B$, which is school climate. This paper concluded that school climate which consists of principal leadership, autonomy, teachers' intimacy, school facilities and services positively influence OCB. The most significant contribution of this paper is the formulation of a theoretical framework which gives a deeper understanding on the relationship between school climate and OCB. The present paper proposed that more empirical studies on OCB in educational context need to be conducted to further illuminate the uniqueness of $O C B$ within an education ecosystem.
\end{abstract}

Keywords: Organizational Citizenship Behavior, School Climate, Education, Extra-Role Behavior

\section{Introduction}

The borderless world requires the education sector in Malaysia to be prepared for the rising wave of the educational transformation system. To ensure that the transformation of Malaysian education is effective and sustainable, the teachers' role has changed. Nowadays, the teachers' role is not only focused on teaching and learning, but also on promoting inclusion and assessing students' performance both in curriculum and co-curriculum (Da Wan et al., 2018). In addition, the development of education in Malaysia is growing rapidly because 
of the high expectations towards teachers and schools at pre-school, primary, and secondary school levels. With the rapid advancement of educational transformation, the nature of school and learning has changed drastically. Hence, the role of teachers is more complicated in order to help the youth explore the borderless world and get connected to their friends across the globe (Ahmad \& Ghavifekr, 2014).

Teachers must make their own decisions on any issue that is related to students such as choosing the instructional/teaching methods and planning for their students' development and assessment. Hence, teachers need to strengthen their capability in terms of knowledge and skills to meet the diverse needs of students, schools and the Ministry of Education (Handler, 2010). In other words, the performance of teachers needs to be enhanced to improve the quality of education. In return, teachers have to be ready to be involved in extrarole behaviors such as working beyond office hours, to ensure the goals of schools and the ministry are accomplished (Oplatka, 2009). In the context of this study, extra-role behaviors refer to organizational citizenship behavior (OCB).

Cohen and Keren (2010) stated that a better understanding of the relationship between climate and OCB can provide the management with more strategies to increase OCB. According to Pozveh and Karimi (2019), leaders with good social and communication skills can create a positive environment in which employees strive to achieve organizational goals, including making efforts beyond the formal and legal requirements of their job. In an educational setting, several studies have been conducted to determine the relationship between climate and OCB (Pozveh \& Karimi, 2019; Farooqui, 2012). However, those studies have been conducted among staff in the higher education system which differs from the school system. Moreover, although several empirical studies have been conducted on the relationship between climate and OCB in schools (Cohen \& Keren, 2010; Garg \& Rastogi, 2006; Tschannen-Moran \& Hoy, 2001), more recent literature is needed to support current studies and to expand the literature (Cohen \& Keren, 2010). Taking into consideration of the above, this paper discusses a comprehensive framework and the theoretical basis explaining the relationship between school climate and OCB.

\section{Organizational Citizenship Behavior}

Smith, Organ, and Near (1983) introduced the term organizational citizenship behavior (OCB). The definitions of OCB have gone through many revisions, but the core constructs were the same (Hoffman et al., 2007). As a result, the rapid growth of research on OCB has contributed to numerous definitions of OCB.

At first, Smith, Organ, and Near (1983) emphasized that OCB is a discretion behavior that people implement without any reward and training provided for the task. Based on such understanding, they suggested that OCB refers to a behavior that provides benefits to the social process in the organization which affects task performance indirectly. Brief and Motowidlo (1986) defined OCB based on three characteristics: (1) OCB should be performed by the members of the organization; (2) this behavior is done at the level of an individual, group, or organization while performing the role of the organization; and (3) the aim of this behavior is to support and improve the effectiveness of the individual, group, and organization's performance. This definition has attracted disputes among scholars, whether be it an in-role and extra-role behavior (Coleman \& Borman, 2000).

Organ (1988) extensively discussed the definition of OCB. He defined OCB as a spontaneous behavior that helps in promoting the effective functioning of the organization without any reward and official appreciation. Workers are free to help others to achieve their 
tasks. It is discretionary, promotes the effectiveness of organizational performance, and is not directly related to the reward system (Wayne \& Green, 1993). This definition emphasizes that the behavior ought to be voluntary in order to promote the organization, whether the role is prescribed or a part of an official duty (Borman \& Motowidlo, 1993). A comprehensive study on the concept of OCB was conducted by Organ (1997) and Schnake (1991). The study suggested that $O C B$ involves a voluntary behavior that does not cause harm to the organizations but tends to increase their effectiveness.

Citizenship behavior includes helping others with job-related problems, volunteering, sharing ideas for new products, making constructive suggestions, punctuality, pushing supervisors to higher standards, making creative suggestions, encouraging workgroup cooperation, and participating in organizational governance (Podsakoff et al., 2000). OCB is also defined as a kind of behavior that emphasizes the discretion of people which is not directly rewarded to enhance the organization's performance (Chib, 2016; Bakhshi, Turnipseed \& Turnipseed, 2013).

\section{School Climate}

Garg and Rastogi (2006) defined school climate as the activities in school including the school practices, teachers' activities, and the communication style among administrators, teachers, parents, and students. In other words, the concepts of school climate tend to affect everyone who is associated with the school including administrators, teachers, students, and parents. In fact, researchers have agreed that positive climates tend to produce positive work attitudes of employees as well as improve organizational performance (Cohen \& Keren, 2010). In another study, school climate is defined as the character of school life based on people's experience of school life which reflects the norms, goals, values, interpersonal relationships, teaching and learning, and school structures (Wang \& Degol, 2016; Cohen et al., 2009).

Scholars have conducted their studies on school climate by looking into several dimensions. Cohen and Keren (2010) divided the dimensions of OCB into eight dimensions which are principal leadership, the supervisors' role, school services, innovation adoption, the teaching load, teacher relationships, autonomy, and prestige. In another study, Beaudoin and Roberge (2015) divided school climate into four dimensions: 1) the students' feeling of safety in school, 2) students' perceived cause of mistreatment where applicable, 3) students' feeling of belonging to the school, and 4) students' general perception of the school environment. Meanwhile, Malinen and Savolainen (2016) divided school climate into four categories: 1) collaboration, 2) student relations, 3) decision making, and 4) instructional innovation. Dubbeld et al. (2019) broke the dimensions of school climate into three categories which are perceptions of school policy, perceptions of school climate for students, and perceptions of school climate for teachers.

Based on the review of school climate dimensions above, school climate is seen as a multi-dimensional concept (Malinen \& Savolainen, 2016) that improves people's understanding of the complexity of values in schools. The dimensions of school climate in the above literature differ from each other and are consistently determined by the objectives of the study. To understand the concepts of school climate, it is necessary to determine the elements or dimensions of school climate. In fact, an essential dimension of the school climate is the school principal's leadership influence on the character of a school and how this dimension enhances the quality of the school entirely (Spicer, 2016). This shows the importance of emphasizing school climate in the literature. 


\section{Influence of School Climate on Organizational Citizenship Behavior (OCB)}

Several studies have attempted to investigate the link between school climate and OCB (Cohen \& Keren, 2010). Literature has shown that a positive school climate leads to school success as well as a higher level of OCB (Nutov \& Somech, 2017; Malinen \& Savolainen, 2016; Farooqui, 2012; Cohen \& Keren, 2010; Garg \& Rastogi, 2006; Dipaola \& Tschannen-Moran, 2001). For this paper, school climate is expected to influence OCB among teachers. School climate is broken down into four specific dimensions: 1) principal leadership, 2) autonomy, 3) teachers' intimacy, and 4) school facilities and services.

\section{1) Principal leadership}

The first dimension of school climate which is principal leadership is related to leadership style. In a supportive school climate, the principals apply constructive criticism in which they respond to teachers' criticism, help teachers after school hours, encourage innovation among teachers, appreciate teachers' work, and the like (Cohen \& Keren, 2010). In short, principals demonstrate strong leadership skills and a good relationship with teachers in school. In the context of this study, principal leadership refers to the leadership style of principals in terms of the extent to which the principals take a personal interest in the teachers and their welfare, manage the school effectively, encourage teachers to go to the extra mile including teaching, respond to teachers' criticism, are concern with school innovation, and encourage teachers to be involved in school's policy-making processes. The leadership of the principal could be characterized as supportive leadership if the principals practice the behaviors stated. Previous findings suggested that such behaviors could create a positive climate to encourage teachers to exhibit OCB in school (Somech \& Ron, 2007). From the discussion on the relationship between principal leadership and $O C B$, the following hypothesis was set to be tested in the current paper.

\section{Hypothesis $1 \mathrm{a}$}

There is a positive and significant relationship between principal leadership and teachers' organizational citizenship behavior.

\section{2) Autonomy}

The second dimension is autonomy, which refers to the degree of freedom teachers feel in doing their job. The autonomy of teachers includes teachers' freedom to choose instructional techniques or teaching methods and freedom to express their feelings through criticism. In other words, teachers feel free to develop their own style of working without feeling dominated by the school principal or other members in the school. A school is characterized as having an autonomous climate when such freedom is present (Cohen \& Keren, 2010). High autonomy means that teachers have the freedom to do their job without having many constraints from other people (e.g., principal, peers, and parents) including rules and regulations. In fact, studies revealed that autonomy is associated positively with OCB (Cohen \& Keren, 2010). Hence, the following hypothesis was set to be tested in the current paper.

Hypothesis $1 b$

There is a positive and significant relationship between autonomy and teachers' organizational citizenship behavior. 


\section{3) Teachers' intimacy}

Teachers' intimacy, the third dimension, refers to the atmosphere among teaching staff, the social relationship among teachers, their sense of belonging, and the absence of conflicts between them (Cohen \& Keren, 2010). Basically, teachers' intimacy describes the teachers' cooperation in school. Such a relationship definitely provides a supportive environment for teachers to exhibit $\mathrm{OCB}$, particularly behaviors in helping other teachers. $\mathrm{A}$ high level of teachers' intimacy among teachers indicates a high level of teachers' tendency to be involved in OCB (Cohen \& Keren, 2010). Hence, the following hypothesis was set to be tested in the current paper.

Hypothesis $1 \mathrm{c}$

There is a positive and significant relationship between teachers' intimacy and teachers' organizational citizenship behavior.

\section{4) School facilities and services}

The fourth dimension; school facilities and services, covers the availability of adequate equipment and the cooperation of support staff (Cohen \& Keren, 2010). It is expected that having adequate services will result in a higher level of OCB. For instance, if there are adequate teaching facilities including technology devices, such as computers in schools, teachers tend to be innovative and creative in implementing new teaching methods which would be of benefit to the students' performance and school image. Therefore, a high score in school facilities and services will lead to a high level of OCB among teachers. Hence, the hypothesis for dimension four is as follows:

Hypothesis $1 d$

There is a positive and significant relationship between school facilities and services and teachers' organizational citizenship behavior.

Based on the review of existing studies on the relationship between school climate and $O C B$, the findings consistently revealed that the more positive the school climate is, the more teachers will exhibit OCB in school. Accordingly, Cohen and Keren (2010) pointed out that when employees' expectations to have support from the organization are met, they will feel happy with the organizational climate. Hence, they will perform well to complete the jobs. Apart from the possibility of positive school climate to increase a higher level of $O C B$, it also contributes to a positive impact on employees' performance (Bogler \& Somech, 2004; Dipaola \& Tschannen-Moran, 2001).

\section{Related Theories}

This current paper employs three theories to explain OCB and its relationship with school climate. First is the Katz and Kahn's theory, second is the social exchange theory (SET), and third is the organizational support theory (OST). The introduction of these theories is explained in the following sections in order to have a clear understanding of the theories.

\section{Katz and Kahn's Theory}

The history of citizenship behavior concept traces back to the theory of Katz in 1964 (Chou \& Stauffer, 2016). The concept of OCB is based on the readiness of people to help others to carry out tasks beyond contractual obligations. Katz and Kahn (1966) stated that there are 
three types of individual behavior that help organizations to be more efficient: 1 ) individuals ought to be involved and stay within the system, 2) individuals ought to have capabilities based on the operating system, and 3 ) individuals ought to show innovation and perform spontaneous behavior to fulfill the function of the organization (Organ, Podsakoff, \& MacKenzie, 2006).

These three types of individual behavior show visible signs of $O C B$, which explain that members of an organization do not only have to meet expectations but must also exceed them to ensure the success of the organization. Scholars revealed that the third feature of effective organization from Katz and Kahn's theory attracted the attention of many scholars (Chou \& Stauffer, 2016). The third behavior which refers to innovative and spontaneous behavior explains that organizations need employees with a desire to succeed beyond the minimum requirement of their jobs and certain aspects of business operations. Many scholars developed their study and derived OCB dimensions based on innovative and spontaneous behavior which were introduced by Katz and Kahn in 1966 (Podsakoff et al., 2000).

Based on Katz and Kahn's theory, innovative and spontaneous behavior include five other characteristics or behaviors which are: 1) cooperating with others such as helping peers who have heavy workload, 2) protecting the organization such as reporting suspicious activities, 3) offering constructive ideas such as demonstrating more effective ways to improve presentation skills in a meeting, 4) self-training such as being involved in courses outside the organization to increase skills related to the job, and 5) maintaining a positive attitude towards the organization such as portraying a positive image of the organization to others (Organ, Podsakoff, \& MacKenzie, 2006).

Katz and Kahn (1966) differentiated between in-role and extra-role behavior. In-role behavior is the behavior that appears within the literal contractual obligation or job description. The behavior can be motivated by the rewards system that is provided by the organization (Organ, Podsakoff, \& MacKenzie, 2006). Rewards include pay given in recognition of the efforts and achievements when employees have successfully accomplished the tasks prescribed.

There are three types of recognition which are known as motivational patterns for inrole performance: 1 ) system rewards, which are offered to individuals who fulfill the standard performance in the formal system, but no incentive is offered for in-role performance above the minimal standard; 2 ) individual instrumental rewards, which provide incentives for in-role performance above the minimal standards, but no incentives for extra-role behavior; and 3) intrinsic rewards, which are incentives for sustaining the operation at a high-quality level but do not necessarily demonstrate supportive actions to others. These motivational patterns are seen as an important element to the organization system (Organ, Podsakoff, \& Mackenzie, 2006). Meanwhile, Katz and Kahn (1966) acknowledged that extra-role behaviors are a sense of citizenship that improves an individual's minimally required in-role performance level. In their study, the concept of spontaneous behavior is used to represent extra-role behavior which arose from the feeling of 'citizenship'. In their later work, Katz and Kahn (1978) defined the concept of a sense of citizenship into a willingness to go the extra mile which is beyond the role expectations.

Notably, Katz and Kahn (1966) emphasized that the differences in motivational patterns (rewards system) may affect the in-role and extra-role behaviors. For instance, the formal rewards system provides incentives to employees who achieve the minimum level of performance (in-role), however, it fails to encourage improvement in terms of incremental performance (extra-role) within the organization (Chou \& Stauffer, 2016). In other words, 
extra-role performance appeared within the system of the organization without involving a formal rewards system of the organization. In summary, Katz and Khan (1966) provided a theoretical basis for OCB, supported by the construct of OCB developed by Organ (1988). Similarly, the current paper uses Katz and Kahn's theory as a theoretical basis of OCB.

\section{Social Exchange Theory (SET)}

Social exchange theory (SET) is developed by Blau in 1964. This theory describes social change and stability as an exchange process within a community from the psychological and sociological perspective. Blau (1964) defined social exchanges as voluntary acts of individuals driven by the expected benefit that they will receive from the result of their relationships with others. In other words, this social exchange relationship requires an individual to benefit another individual with the expectation to earn the same benefit in the future (Ababneh \& Hackett, 2019).

Blau (1964) pointed out that the theory of social exchange provides a mechanism to the relationship between intuition and attitudes. This means that most of the work at the workplace does not follow the set rules but rather the discretion. This statement is supported by Zeinabadi and Salehi (2011) who viewed the behavior of employees developed by the social exchange as behavior performed beyond his/her contract of employment. This situation exists when an employee feels good and happy with the services or appreciation that he/she receives. In return, they tend to give the same reward in the future (Arshad \& Zawawi, 2010).

Furthermore, the theory of social exchange explains social relationships which include the elements of reward, sacrifice, and mutual influence. The rewards are the benefits received from the sacrifices made. Sacrifices are unavoidable for the sake of the relationship. Meanwhile, profit is the reward obtained from the sacrifices made. This relationship often goes beyond economic value, support, attention, respect, and beneficial interest in relation to the personnel's relationship with other beneficial people (Blau, 1964).

Elstad et al. (2011) stated that the SET describes OCB theoretically. Many scholars use this theory to explain OCB which is performed by employees in an organization (Ababneh \& Hackett, 2019; Becton et al., 2017). Social exchange relationships create a sense of responsibility for employees to repay the benefits that they receive from the organization through engaging in OCB (Zeinabadi, 2010). In other words, employees who are involved in social exchange relationships tend to show positive behavior in the organization. For example, teachers who are treated well by the administrator or colleagues will feel that they need to demonstrate good behavior to help the school achieve its goals (Elstad et al., 2011), including going the extra mile in performing the tasks. It seems that when the teachers' requirements of social relationships are met, it would allow individuals to act positively towards the organization. In other words, the desire to meet the needs of the individual is a natural motive for human behavior. However, the motivation cannot be taken for granted because environmental factors can promote or inhibit the natural tendency to act to meet the needs (Koca, 2016). This is due to the failure or dissatisfaction to fulfill their needs in a social relationship or work achievement.

For instance, a heavy workload in school could lead to dissatisfaction in work achievement (Apaydin, 2012). It will affect teachers' psychological function and behavior. Consequently, they tend to exhibit negative behavior. SET shows that climate in schools contributes to prosperity and tends to indicate either a positive or negative behavior in 
schools. In the context of the current paper, SET is adapted to support the relationship between SC and OCB.

\section{Organizational Support Theory (OST)}

The organizational support theory (OST) was introduced by Eisenberger et al. (1986). OST began with the assumption that employees often symbolize the organization as a different unit in which they act in accordance with their attitudes and motives. This theory assumes that the development of employees' support is encouraged by the organization (Rhoades \& Einsberger, 2002). In other words, OST describes the relationship between employees and the organization. Employees not only develop their perception about the organization, but also become an agent to represent and act on behalf of the organization.

OST emphasizes that employees will create their beliefs about the actions of the organization such as the support given, the policies implemented, facilities provided, and the behavior shown by the representatives of the organization (top management level). This theory suggests that employees establish their beliefs in an organization through the way the organization is concerned about their well-being and appreciation towards their contribution in accomplishing the organization's goals and objectives (Kim, Eisenberger \& Baik, 2016). The beliefs exist when the representative of the organization such as team leaders have direct contact with the employees and engage in the feedback process, decision making, and resource allocation (Eisenberger et al., 1986). That means an appropriate or inappropriate leaders' action is not only an indicator of support by the leaders but also the support of the organization. Therefore, employees will make judgments on the leaders' actions based on their expectations and individual beliefs. Hence, employees will create perceptions of how much support is provided by the organization. Notably, such perceptions will create a sense of responsibility for the organization in the workforce. In addition, it also encourages employees to help the organization achieve its goals and objectives, and perform beyond the required task.

Therefore, the support of the organization that is addressed by the employees can provide an impression such as work-related attitudes, work behavior, and interactions between employees and the organization (Rhoades \& Eisenberger, 2002). This theory also explains the employment relationship. An organization that provides a wide range of benefits in terms of support, work situation, and the discretion of its employees will, in turn, encourage them to work more and to increase their effort in terms of additional roles which is called OCB to assist the organization's success. For the purpose of this paper, the OST is used to support the relationship between school climate and OCB among teachers.

\section{Theoretical Framework}

As discussed in the previous sections, the aim of this paper is to determine the relationship between school climate and OCB. Scholars revealed that the understanding of the OCB concept and the relationship between $\mathrm{SC}$ and $\mathrm{OCB}$ may guide school administrators in helping teachers to exhibit OCB in schools (Nutov \& Somech, 2017). However, it is important to understand the way OCB is constructed and how school climate and OCB can be related. This situation can be explained by the relevant theories. For this paper, OCB is explained by Katz and Kahn's theory. Meanwhile, there are two theories that explain the relationship between $\mathrm{SC}$ and $\mathrm{OCB}$, which are the social exchange theory (SET) and organizational support theory (OST). 
Katz and Kahn's theory with the distinction between innovative and spontaneous performance and behavior of employees are among the first theories of OCB in the 70s and 80s. In their study, the innovative and spontaneous behavior of employees was one of the components to increase the efficiency of the organization. Innovative and spontaneous behavior includes five characteristics namely: 1) cooperation with others, 2) organization conservation, 3) voluntary constructive ideas, 4) self-training, and 5) maintaining a positive attitude towards the organization (Chou \& Stauffer, 2016). These characteristics of innovative and spontaneous behavior have provided the dimensions of OCB. Hence, the theory of Katz and Kahn explains the construct of OCB.

Some scholars have attempted to investigate the causes of OCB. Vigoda-Gadot (2007) stated that employees may engage in OCB because they are forced by their abusive supervisors and are pressured by peers and management to improve organizational performance, productivity, and image. Spector and Fox (2010) argued that sometimes, employees may engage in OCB because of organizational constraints (e.g., rules and procedures and inadequate equipment or supplies), supervisory requests (e.g., unexpected circumstances, such as replacing a peer who is sick), and inadequate co-workers. In the context of this paper, those causes are reflected in the school climate which comprises of principal leadership, autonomy, teachers' intimacy, and school facilities and services. As discussed earlier, SET and OST were used to explain the relationship between school climate and OCB.

The SET, developed by Blau (1964), refers to the voluntary acts of individuals that are driven by the result of exchanging relationships with others. From the perspective of this theory, the reciprocity norm plays an important role in social exchange. The individual tends to do good while expecting to receive good feedback in terms of social relationships. In the context of this paper, social relationship refers to the relationship between teachers and schools. It is expected that a good school climate provided by school administrators tends to develop positive behavior among teachers. Teachers expect to exhibit more OCB when they work in a good school climate such as having a good principal, a high level of autonomy, good relationships with other teachers, and adequate school facilities and services. In other words, with the increase in school climate positivity, more teachers will exhibit OCB. Hence, this theory supports the relationship between school climate and OCB.

Another theory that supports the relationship between school climate and OCB is the OST. In the context of this paper, organizational support refers to services provided by schools in terms of social relationships, job demand, and facilities. These elements of organizational support seem to build a school culture of trust and good work behavior of teachers in school. In addition, it will create a sense of responsibility for the organization. In return, teachers are motivated to go the extra mile in performing the tasks and increase their effort to do the best for the members of the school and the school itself. For instance, one of the school climate's dimensions is the principal's leadership style. In a positive school climate, the principal values teachers' work, encourages their involvement in the policy-making process, and motivates teachers' innovative work. These are the examples of behaviors that demonstrate a good leadership style by principals. It is expected that such behavior by the principal will create a conducive environment for teachers to exhibit OCB (Somech \& Ron, 2007). Hence, OST explains the relationship between school climate and OCB. To sum up, the theoretical framework of this paper is illustrated in Figure 1. 


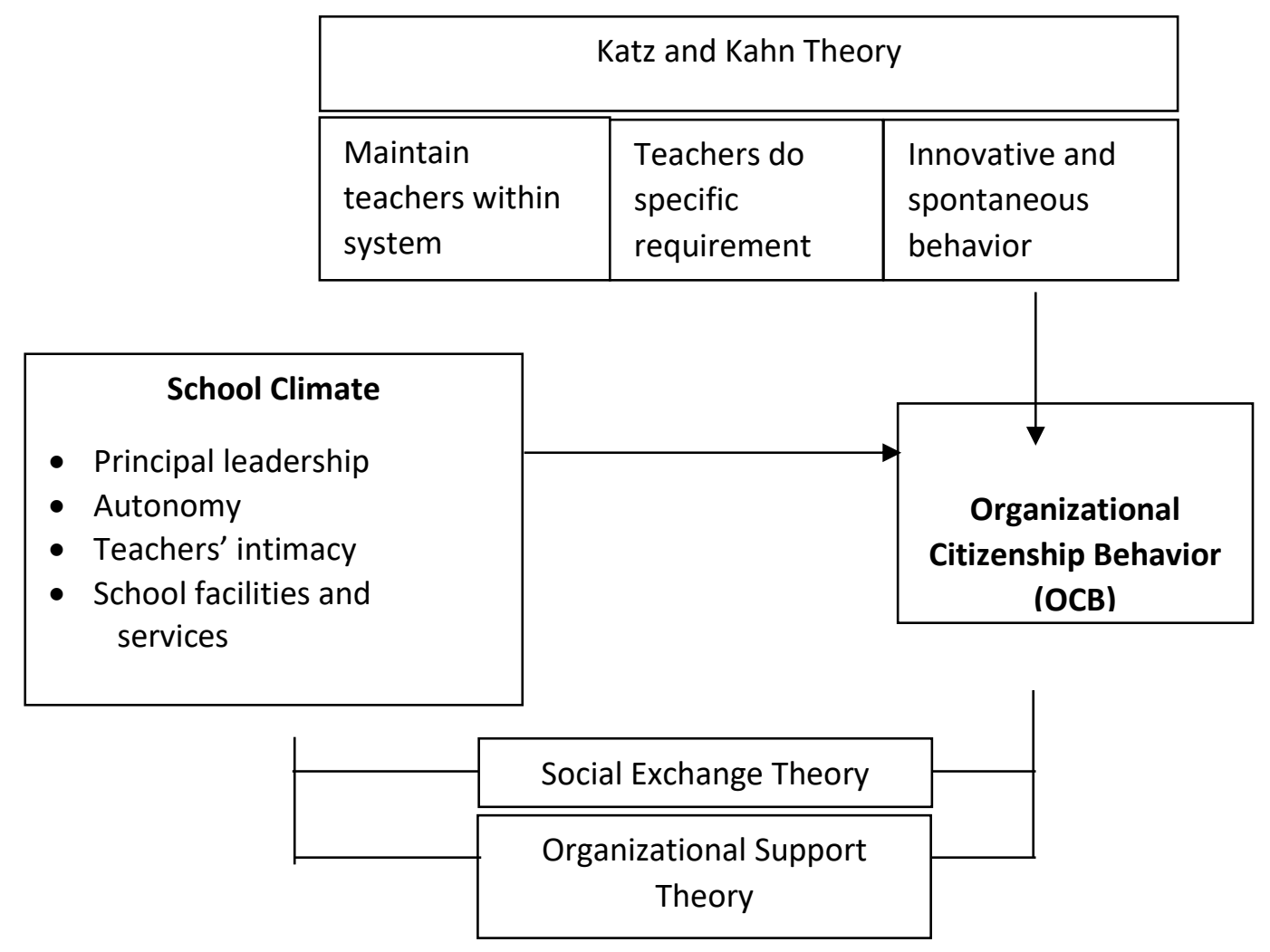

Fig. 1 Theoretical Framework OCB within a school ecosystem

\section{Conclusion}

Previous investigations of OCB tended to focus on the influence of school climate on OCB. However, little attention has been given to the theories that explained the relationship between school climate and OCB. The primary purpose of this paper was to fill this void. We investigated the direct effect of school climate (principal leadership, autonomy, teachers' intimacy, and school facilities and services) and OCB by supporting the established theories.

The review of literature clearly suggests that school climate influences OCB. Indeed, principal leadership, autonomy, teachers' intimacy, and school facilities and services are considered as predictors of extra-role behaviors among teachers. First, the literature suggests that teachers tend to exhibit OCB when the principal has strong leadership skills and a good relationship with teachers in the school. Teachers tend to develop a positive behavior when their requirements of social relationships are fulfilled. From our review of the literature, principal leadership is seen to be a major contribution to OCB among teachers. The reason for this statement is that because a principal can control the school climate by providing a supportive environment such as autonomy and adequate facilities to the teachers. Second, the literature suggests that teachers tend to perform an extra-role behavior when they are given the autonomy to do the tasks. Sometimes teachers tend to do tasks beyond the prescribed work because they have the freedom to make decisions on what they are doing. They feel like they have the power to perform the job based on creativity and comfortability. Hence, they tend to perform their job without taking into consideration the working hours such as attending school activities after school hours, organizing tuition classes for students for free, and so on.

Third, teachers' intimacy can be seen as an encouragement of OCB. Teachers' intimacy can be in a form of social relationship that enhances OCB among teachers. We believe that a 
positive relationship among teachers will encourage teachers to perform extra-role behaviors such as helping other teachers to complete the tasks, helping other teachers who have workrelated problems, and so on. We found that teachers' intimacy should also be given attention by the school's administration to create a positive school climate. A good social relationship among teachers could enhance the teachers to exhibit $O C B$, which in return will benefit the school entirely. The fourth school climate's dimension is school facilities and services. Adequate school facilities and good services provided by the school are believed to encourage teachers to do tasks beyond the prescribed work. It also creates a positive climate in the school when teachers are satisfied with the facilities and services of the school.

One major contribution of our paper is the explanation of the relationship between school climate and OCB based on the theoretical perspective. From our review, the construct of teachers' OCB represents voluntary behavior among teachers that is not directly related to the rewards system and increases school effectiveness. Similar to previous studies, we expect that teachers who are in a supportive school climate, such as having a good principal (principal leadership), having the freedom to do the job (autonomy), having a good relationship with colleagues (teachers' intimacy), and receiving adequate school's facilities and services tend to engage in OCB. Additionally, based on the SET and OST, research has confirmed that when a teacher has a good social relationship with others in school and receives support from the school, he or she is more likely to exhibit OCB both in and outside school. Although there are many factors that can contribute to $O C B$, we only attempted to investigate the influence of school climate on OCB which received little attention among scholars. Hence, this paper could be a reference for future researchers to expand the literature on the relationship between school climate and OCB. Lastly, the most significant contribution of this paper is that it provides the theoretical framework which gives a deeper understanding of the relationship between school climate and OCB.

\section{Reference}

Ababneh, K. I., \& Hackett, R. D. (2019). The direct and indirect impacts of job characteristics on faculty organizational citizenship behavior in the United Arab Emirates (UAE). Journal of Higher Education, 77, 19-36. https://doi.org/10.1007/s10734-018-0252-3.

Ahmad, R., \& Ghavifekr, S. (2014). School Leadership for The 21st Century: A Conceptual Overview. Malaysian Online Journal of Educational Management, 2(1), 48-61.

Apaydin, C. (2012). The workload of faculty members: the example of educational faculties in Turkey. College Student Journal, 46(1), 203-213.

Arshad, R., \& Zawawi, A. S. (2010). Tanggapan sokongan organisasi, kepuasan kerja, komitmen dan kelakuan kewargaan organisasi pekerja: Peranan politik organisasi sebagai perantara. Jurnal Pengurusan, 31, 83-92.

Bakhshi, A., Kumar, K., \& Rani, E. (2009). Organizational justice perceptions as predictor of job satisfaction and organization commitment. International of Business and Management, 4(9), 145-154.

Beaudoin, H., \& Roberge, G. (2015). Student perceptions of school climate and lived bullying behaviours. Procedia - Social and Behavioral Sciences, 174, 321-330. doi: 10.1016/j.sbspro.2015.01.667.

Blau, P. M. (1964). Exchange and Power in Social Life. New York: John Wiley.

Borman, W. C., \& Motowidlo, S. J. (1993). Expanding the criterion domainto include elements of contextual performance, In N. Schmitt, W. C., Borman, and Association (Eds). San Francisco: Jossey-Bass. 
Brief, A. P., \& Motowidlo, S. J. (1986). Prosocial organizational behvaiors. Academy of Management Review, 11, 710 - 725.

Chib, S. (2016). Study on organizational commitment and workplace empowerment as predictors of organization citizenship behaviour. Journal of Management and Development 3(3), 63-73. doi: 10.19085/journal.sijmd030301.

Chou, S. Y., \& Stauffer, J. M. (2016). A theoretical classification of helping behavior and helping motives. Personnel Review, 45(5), 871-888, https://doi.org/10.1108/ PR-03-2015-0076.

Cohen, A., \& Keren, D. (2010). Does climate matter? An examination of the relationship between organisational climate and OCB among Israeli teachers. The Service Industries Journal, 30(2), 247-263. doi:10.1080/02642060802120158.

Cohen, J., McCabe, L., Michelli, N. M., \& Pickeral, T. (2009). School climate: Research, policy, practice, and teacher education. Teachers College Record, 111, 180-213.

Coleman, V. I., \& Borman, W. C. (2000). Investigating the underlying structure of the citizenship performance domain. Human Resource Management Review, 10, 25-44.

Da Wan, C., Sirat, M., \& Abdul Razak, D. (2018). Education in Malaysia towards a developed nation. ISEAS, Yusof Ishak Institute, 4, 1-19.

Dipaola, M. F. \& Tschannen-Moran, M. (2001). Organizational citizenship behavior in schools and its relationship to climate. Journal of School Leadership, 11(5), 42 - 47.

Dubbeld, A., de Hoog, N., den Brok, P \& de Laat, M. (2019). Teachers' multicultural attitudes and perceptions of school policy and school climate in relation to burnout. Intercultural Education, 1-19. doi: 10.1080/14675986.2018.1538042.

Elstad, E., Christophersen, K. A. \& Turmo, A. (2011). Social exchange theory as an explanation of organizational citizenship behavior among teachers. International Journal of Leadership in Education, 14(4), 405-421. Doi: 10.1080/13603124.2010.524250.

Eisenberger, R., Armeli, S., Rexwinkel, B., Lynch, P. D., \& Rhoades, L. (2001). Reciprocation of perceived organizational support. Journal of Applied Psychology, 86, 42-51.

Eisenberger, R., Huntington, R., Hutchinson, S., \& Sowa, D. (1986). Perceived organizational support. Journal of Applied Psychology, 71(3), 500-507.

Farooqui, M. R. (2012). Measuring organizational citizenship behavior (OCB) as a consequence of organizational climate (OC). Asian Journal of Business Management, 4(3), 294-302. doi:www.maxwellsci.com/print/ajbm/v4-294-302.pdf.

Garg, P. \& Rastogi, R. (2006). Climate profile and OCBs of teachers in public and private schools of India. International Journal of Educational Management, 20 (7), 529 - 541. doi:10.1108/09513540610704636.

Giorgi, G., Dubin, D., \& Perez, J. F. (2016). Perceived organizational support for enhancing welfare at work: A regression tree model. Frontiers in Psychology, 7, 1-9.

Handler, B. (2010). Teacher as curriculum leader: A consideration of the appropriateness of that role assignment to classroom-based practitioners. International Journal of Teacher Leadership, 3(3), 32-42.

Hoffman, B. J., Blair, C. A., Meriac, J. P., and Woehr, D. J. (2007). Expanding the criterion domain? A quantitative review of the OCB literature. Journal of Applied Psychology, 92(2), 555-566.

Katz, D., \& Kahn, R. L. (1966). The social psychology of organizations. NewYork: Wiely.

Katz, D., \& Kahn, R. L. (1978). The social psychology of organizations. New York: Wiely.

Kim, K. Y., Eisenberger, R., \& Baik, K. (2016). Perceived organizational support and affective organizational commitment: Moderating influence of perceived organizational competence. Journal of Organizational Behavior, 37, 558-583. 
Koca, F. (2016). Motivation to Learn and Teacher-Student Relationship. Journal of International Education and Leadership, 6(2), 1 -20.

Malinen, O. P., \& Savolainen, H. (2016). The effect of perceived school climate and teacher efficacy in behavior management on job satisfaction and burnout: A longitudinal study. Journal of Teaching and Teacher Education, 144-152.

Nutov, L., \& Somech, A. (2017). Principals Going Above and Beyond: Understanding Organizational Citizenship Behavior Among School Principals. Journal of School Leadership, 27, 184-212.

Oplatka, I. (2009). Organizational citizenship behavior in teaching the consequences for teachers, pupils and the school. International Journal of Educational Management, 23(5), 375-389. doi:10.1108/09513540910970476.

Organ, D. W. (1988). Organizational Citizenship Behaviour: The Good Soldier Syndrome. Lexington Book.

Organ, D. W. (1997). Organizational citizenship behavior: It's construct clean-up time. Human Performance, 10, 85 - 97.

Organ, D. W., Podsakoff, P. M., \& MacKenzie, S. B. (2006). Organizational citizenship behavior: Its nature, antecedents, and consequences. USA: Sage Publications, Inc.

Podsakoff, P. M., Mackenzie, S. B., Paine, J. B., \& Bachrach, D. G. (2000). Organizational citizenship behaviors: A Critical review of the theoretical and future research. Journal of Management, 26(3), 513-563.

Pozveh, A. Z., \& Karimi, F. (2019). The relationship between organizational climate and organizational citizenship behaviors of the staff members in the Department of Education in Isfahan city. International Journal of Educational and Psychological Researches, 3, 53-60.

Rhoades, L., \& Eisenberger, R. (2002). Perceived organizational support a review of the literature. Journal of Applied Psychology, 87, 698-714.

Schnake, M. (1991). Organizational citizenship: A review, proposed model and research agenda. Human Relation, 44(7), 735 - 759.

Spicer, F. (2016). School culture, school climate, and the role of the principal (Doctoral dissertation). Retrived from Educational Policy Studies Dissertations, https://scholarworks.gsu.edu/eps_diss/140/.

Spector, P. E., \& Fox, S. (2010). Counterproductive work behavior and organisational citizenship behavior: Are They opposite forms of active behavior? Applied Psychology: An International Review, 59(1), 21-39. doi: 10.1111/j.1464-0597.2009.00414.x.

Somech, A., \& Ron, I. (2007). Promoting organizational citizenship behavior in schools: The impact of individual and organizational characteristics. Educational Administration Quarterly, 43(1), 38-66. doi:10.1177/0013161X06291254.

Smith, C. A., Organ, D. W., \& Near, J. P. (1983). Organizational citizenship behavior: its nature and antecedents. Journal of Applied Psychology, 68, 653 - 663.

Vigoda-Gadot, E., Beeri, I., Birman-Shemesh, T., \& Somech, A. (2007). Group level organizational citizenship behavior in the education system: a scale of reconstruction and validation. Educational Administration Quarterly, 43(4), 462 - 493.

Wang, M. T., \& Degol, J. (2016). School climate: A review of the construct, measurement, and impact on student outcomes. Educational Psychology Review, 28(2), 315 - 352. doi:10.1007/s10648-015-9319-1.

Wayne, S. J., \& Green, S. A. (1993). The effects of leader-member exchange on employee citizenship and impression management behavior. Journal of Human Relations, 46(12), 
1431-40.

Zeinabadi, H., \& Salehi, K. (2011), Role of procedural justice, trust, job satisfaction, and organizational commitment in organizational citizenship behavior (OCB) of teachers: Proposing a modified social exchange model. Procedia-Social and Behavioral Sciences, 29, 1472-1481, doi:10.1016/j.sbspro.2011.11.387. 